\title{
ADDITION OF ESSENTIAL OILS AND MEDIUM CHAIN FATTY ACIDS IN THE DIETS AND THEIR EFFECT ON PRODUCTIVE PERFORMANCE OF BROILER CHICKENS
}

\author{
E. M. Omar ${ }^{1}$, W.H.A. Mohamed ${ }^{2}$, Hala M. Abdel Wahed ${ }^{2}$ and Mona S. Ragab ${ }^{1}$ \\ ${ }^{l}$ Poultry Department, Faculty of Agriculture, Fayoum University, Fayoum, Egypt. \\ ${ }^{2}$ Animal Production Institute, Agriculture Research Center, Ministry of Agriculture, Dokki, Giza, \\ Egypt.
}

(Received 20/11/2019, accepted 14/1/2020)

\section{SUMMARY}

A total number of 180 one-day old unsexed Cobb broiler chickens were initially fed a control diet for six days, then were divided into six treatments (30 birds each), each treatment contained three replicates of ten birds, and the objectives were to evaluate the effects of single or combined supplementation of essential oils (EOs) and medium chain fatty acids (MCFAs) to broiler diets on productive performance. The experimental treatments were as follows: 1- Chicks were fed the control diet $\left(\mathrm{D}_{1)} \cdot 2-\mathrm{D}_{1}+0.1 \mathrm{~g}\right.$ thyme oil $/ \mathrm{kg}$ diet. $3-\mathrm{D}_{1}+0.2 \mathrm{~g}$ thyme oil $/ \mathrm{kg}$ diet. $4-\mathrm{D}_{1}+1 \mathrm{~g}$ aromabiotic $/ \mathrm{kg}$ diet. $5-\mathrm{D}_{1}+1 \mathrm{~g}$ aromabiotic $/ \mathrm{kg}$ diet $+0.1 \mathrm{~g}$ thyme oil $/ \mathrm{kg}$ diet. $6-\mathrm{D}_{1}+1 \mathrm{~g}$ aromabiotic $/ \mathrm{kg} \mathrm{diet}+0.2 \mathrm{~g}$ thyme oil/kg diet. Results obtained could be summarized in the following: The higher significantly value of live body weight at 38 day and body weight gain during the period from 7 to 38 days were obtained for chicks control diet. Inclusion of single or combined supplementation of EOs and MCFAs in the broiler diets at different levels had insignificant effects on feed intake during all periods studied. Chicks fed combined supplementation of EOs and MCFAs experimental diet $(0.1 \mathrm{~g}$ EOs $/ \mathrm{kg} \mathrm{diet}+0.1 \%$ MCFAs) had best significantly feed conversion ratio during the period from 7-38 days of age compared with those fed the control diet and some other treatment. Combined supplementation of EOs and MCFAs to broiler diets caused significantly improves in performance index during the finisher period compared with those fed diets supplemented with MCFAs alone or the control. Chicks fed experimental diet containing $0.2 \mathrm{~g}$ EOs/ $\mathrm{kg}$ diet+ $0.1 \%$ MCFAs had significantly higher thymus and spleen $\%$ compared with those fed MCFAs alone, EOs alone and the control. Chicks fed diets supplemented with $0.2 \mathrm{~g} \mathrm{EOs} / \mathrm{kg}$ diet+ $0.1 \%$ MCFAs had higher value of lymphocyte (lower values of eosinophiles, alanine aminotransferase, aspartate aminotransferase, total lipids, triglycerides and total cholesterol), Chicks fed diet containing $0.1 \mathrm{~g}$ EOs $/ \mathrm{kg}$ diet had higher intestinal $\mathrm{pH}$, while; chicks fed diet containing $0.1 \%$ MCFAs resulted in the lower intestinal $\mathrm{pH}$ values (higher values of total count). The lower value of E.coli (significantly higher lactobacillus count) was obtained for chicks fed diet containing $0.2 \mathrm{~g} \mathrm{EOs} / \mathrm{kg}$ diet+ $0.1 \%$ MCFAs. Chicks fed with $0.1 \mathrm{~g}$ EOs $/ \mathrm{kg}$ diet $+0.1 \%$ MCFAs had the highest economic and relative efficiency values during the period from 7 to 38 days.

Keywords: Feed additives, Moringa oleifera leaf meal, thyme oil, aromabiotic, probiotics and broilers.

\section{INTRODUCTION}

Feed contributes $65-70 \%$ of total cost of poultry production. Economical broiler production largely depends on optimum utilization of feed, improved body weight, prevention of diseases and reduced mortality rate. Use of chemical feed additives as growth promoters has criticism due to adverse effects on consumers and there is increasing demand for organic meat and eggs.

There is currently a world trend to reduce the use of antibiotics in animal feed due to the contamination of meat products with antibiotic residues (Menten, 2001) as well as the concern that some therapeutic treatments for human diseases might be jeopardized due to the appearance of resistant bacteria (Silva Cardoso et al., 2012). The European Union reported that about 25000 patients died each year from infections caused by drug-resistant bacteria, which is equivalent to $€ 1.5$ billion of medical healthcare costs (Ziggers, 2011). The recent trend in the feed business is currently directed 


\section{Omar et al.}

toward the use of natural ingredients as alternatives to antibiotics, synthetic colors, and other chemicals.

A number of alternative products, such as probiotics, prebiotics, organic acids, essential oils, and oligosaccharides, are the subject of research to enhance the health of human and growth performance of broilers. Developments in poultry nutrition have generally been driven by the need to sustain genetic potential within the confines of ever evolving systems of poultry production (Leeson, 2008).

A poultry industry challenge is to exploit the use of specific dietary supplements to boost the production and growth performance of poultry (Khan, 2014). Several alternatives to these growth promoters have been proposed and organic acids, medicinal plants as natural feed additives are now recently used in poultry diet to enhance the performance of the immune response of birds (Saki et al., 2012).

Essential oils are volatile, aromatic oily liquids distilled from plant parts and have a characteristic aroma and unique composition. They are complex mixtures of chemical compounds such as terpenes, terpenoids, aldehydes, alcohols, phenols, methoxy-derivatives and a few others of which terpenes are the most common. A detailed classification could be found in other reviews (Kollanoor Johny and Venkitanarayanan, 2017 and Adaszynska-Skwirzynska and Szczerbinska, 2018). Usually, an EOs will contain several components with two or three major ones at large concentrations ranging from $20 \%$ to $70 \%$. Although potentially differing in their constituents, properties that are common to most essential oils include being vaporized with steam, lipophilic nature, liquid state at 180C, optically active (ability of EOs components to rotate the plane of planepolarized light which is an indicator of quality and purity), and solubility in ethanol and lipids (Adaszynska-Skwirzynska and Szczerbinska, 2018). Major aromatic oils that may have potential in poultry production and processing include nutmeg, lime, mandarine, orange, rosewood, oregano, mountain savory, fennel, turmeric, rosemary, sage, cinnamon, thyme, ginger, eucalyptus, garlic, pimenta, lemongrass, and clove (Kollanoor Johny and Venkitanarayanan, 2017; Adaszynska-Skwirzynska and Szczerbinska, 2018 and Dewi et al., 2018). These essential oils can be used as additives in feed or drinking water in live production, or as antibacterials for the processing of poultry products. Beneficial effects of essential oils are attributed mainly to their antibacterial, antifungal, antiviral, antioxidant, and immunostimulant activities (Kollanoor Johny and Venkitanarayanan, 2017; Adaszynska-Skwirzynska and Szczerbinska, 2018). Also, their function in improving gut health has been reviewed recently, and has been attributed to their digestive conditioning, antibacterial, and microbiome modulation properties (Nair, 2019). Additionally, other reviews have reported their potential to become replacers of antibiotic growth promoters resulting in improved weight and feed conversion ratio. More specifically, essential oils of peppermint, ginger, thyme, oregano, and some combinations have been reported to improve the average daily gain in broiler chickens (Adaszynska-Skwirzynska and Szczerbinska, 2018).

Among a variety of candidates for the replacement of antibiotic growth promoters, organic acids (OAs) are promising alternatives (Mroz, 2005). Medium-chain fatty acids (MCFAs) are another type of acids that could be considered as antibiotic replaces. Medium chain fatty acids are namely caproic, caprylic, or capric acid and are digested and absorbed faster than long-chain fatty acids and may be very useful when the digestion, absorption, or transport of dietary fat is defective (Del Alamo et al., 2007). Medium chain fatty acids have been shown to be good alternatives for nutritional antibiotics in piglets, due to their high antibacterial activity, and they enter the cell un-dissociated (Dierick et al., 2002). Once in the cell, the MCFAs dissociates followed by a drop in $\mathrm{pH}$ and results in the inactivation of the bacterial cell. The MCFAs inhibits the production of lipases by the bacteria. As lipases are needed to allow the bacteria to attach to the intestinal wall, this process will be prohibited and the bacteria will be washed out (Dierick et al., 2002). Furthermore, the antibacterial potency of MCFAs is believed to exceed that of short chain fatty acids, SCFAs (Hermans et al., 2010). During the first week, MCFAs are important players in the build-up and maintenance of the poultry's health (Ding and Lilburn, 1997).

Considering the above statements, one experiment was conducted to study the effects of single or combined supplementation of EOs and MCFAs to broiler diets on growth performance, mortality rate, some carcass parameters, bacterial count, intestinal $\mathrm{pH}$, blood serum parameters and economical efficiency. 


\section{MATERIALS AND METHODS}

The experimental work of the present study was carried out at El-Azab Poultry Research Station, Fayoum, Animal Production Research Institute, Agricultural Research Center, Ministry of Agriculture, Dokki, Egypt, during the period from February to April 2016. Chemical analyses were performed in the laboratories of the Animal Production Research Institute, Agricultural Research Center according to the procedures outlined by A.O.A.C. (2016).

The aim of the experiment was to study effects of essential oils (thyme oil) and their combination with MCFAs (aromabiotic) to broiler diets on growth performance, carcass parameters, bacteria enumeration, intestinal $\mathrm{pH}$, blood serum parameters, immune parameters and economical efficiency of broiler chicks.

The total number of the experimental birds (180 at seven days of age) was divided into six treatments (30 birds each), each treatment contained three replicates of ten birds.

The experimental treatments were as follows: 1-Chicks were fed the control diet $\left(\mathrm{D}_{1}\right), 2-\mathrm{D}_{1}+0.1 \mathrm{~g}$ thyme oil $/ \mathrm{kg}$ diet, $3-\mathrm{D}_{1}+0.2 \mathrm{~g}$ thyme oil $/ \mathrm{kg}$ diet, $4-\mathrm{D}_{1}+1 \mathrm{~g}$ aromabiotic $/ \mathrm{kg}$ diet, $5-\mathrm{D}_{1}+1 \mathrm{~g}$ aromabiotic $/ \mathrm{kg}$ diet $+0.1 \mathrm{~g}$ thyme oil $/ \mathrm{kg}$ diet, $6-\mathrm{D}_{1}+1 \mathrm{~g}$ aromabiotic $/ \mathrm{kg}$ diet $+0.2 \mathrm{~g}$ thyme oil $/ \mathrm{kg}$ diet.

The experimental diet was supplemented with minerals and vitamins mixture and DL-methionine and $\mathrm{L}-\mathrm{Ly}$ sine $\mathrm{HCl}$ to cover the recommended requirements according to the Cobb strain catalog recommendations and were formulated to be iso-caloric and iso-nitrogenous. The composition and calculated analysis of the experimental diet are shown in Table (1).

Chicks were raised in electrically heated batteries with raised wire mesh floors and had a free access to the feed and fresh water from nipple drinkers (2nipples/cage) throughout the experiment. Light was provided for $23 \mathrm{~h} / \mathrm{d}$. Batteries were placed into a room provided with continuous fans for ventilation. The chicks were fed starter diet from 7 to 14 days of age, grower diet from 15 to 21 days, and finisher diet from 23 days to the end of the experiment at 38 days of age.

Thyme oil purchased from squeeze and extraction medicinal and aromatic oils unit, National Research center, Egypt. Prodused by vitamax coumpany and contains $60 \%$ MCFA (C6, C8, C10) on a support of silicium dioxide. A carefully balanced mix of medium chain fatty acids (MCFA); C6, Caproic Acid, C8, Caprylic Acid, C10, Capric Acid.

Birds were individually weighed to the nearest gram at 7, 15, 22 and 38 days of age in the early morning before receiving any feed and water. At the same time, feed consumption was recorded and body weigh gain (BWG), feed conversion ratio (FCR), crude protein conversion (CPC), caloric conversion ratio $(\mathrm{CCR})$ and growth rate $(\mathrm{GR})(\mathrm{g}$ feed/g gain) were calculated. Performance index $(\mathrm{PI})$ was calculated according to the equation described by North (1981) as follows: PI= (live body weight (LBW), $\mathrm{Kg} / \mathrm{FC}$ ) $\mathrm{x} 100$. The vaccination program adopted by recommended requirements according to standard commercial guidelines. Accumulative mortality rate was obtained by adding the number of dead birds during the experiment divided by the total number of chicks at the beginning of the experimental period.

At the end of the experiments (38 days of age), slaughter tests were performed using 48 chicks (16 treatments $\mathrm{x}$ three replicate). The birds were on feed withdrawal overnight (approximately $12 \mathrm{~h}$ ), then individually weighed to the nearest gram, and slaughtered by severing the jugular vein (Islamic method). After four minutes bleeding time, each bird was dipped in a water bath for two minutes, and feathers were removed. After the removal of head, carcasses were manually eviscerated, and then their weights were obtained. The eviscerated weights included the front part with wings and hind part.

$$
\text { Carcass } \%=(\text { carcass weight/LBW }) \times 100 .
$$

Immune organs (spleen, bursa and thymus glands), viscera (gizzard empty, liver and heart) were individually weighed and calculated in relation to LBW. The abdominal fat was removed from the parts around the viscera and gizzard and was weighed to the nearest gram. Dressing percentage was calculated as follows: Dressing\% $=(($ carcass weight+giblets $) / \mathrm{LBW}) \times 100$. 
Table (1): Composition and analyses of the control (starter, grower and finisher) diets.

\begin{tabular}{|c|c|c|c|}
\hline Item $\%$ & $\begin{array}{c}\text { Starter } \\
\text { (7-14 days) }\end{array}$ & $\begin{array}{c}\text { Grower } \\
\text { (15-21days) }\end{array}$ & $\begin{array}{c}\text { Finisher } \\
\text { (22-38 days) }\end{array}$ \\
\hline Yellow corn, ground & 64.37 & 70.4 & 74.22 \\
\hline Soybean meal (44\%CP) & 23.08 & 16.78 & 12.3 \\
\hline Corn gluten meal $(60 \% \mathrm{CP})$ & 8.56 & 9.0 & 10.0 \\
\hline Dicalcium phosphate & 1.8 & 1.7 & 1.5 \\
\hline Calcium carbonate & 0.9 & 0.85 & 0.8 \\
\hline Vit. and Min. premix ${ }^{*}$ & 0.3 & 0.3 & 0.3 \\
\hline Sodium chloride & 0.3 & 0.3 & 0.3 \\
\hline DL-Methionine & 0.24 & 0.2 & 0.15 \\
\hline L-Lysine $\mathrm{Hcl}$ & 0.45 & 0.47 & 0.43 \\
\hline Total & 100.0 & 100.0 & 100.0 \\
\hline \multicolumn{4}{|l|}{ Calculated analysis $\%^{* *}$ : } \\
\hline Crude protein $(\mathrm{CP})$ & 21.50 & 19.5 & 18.5 \\
\hline Crude fat & 2.84 & 3.03 & 3.17 \\
\hline Crude fiber & 3.00 & 3.00 & 3.00 \\
\hline Calcium & 0.90 & 0.84 & 0.76 \\
\hline Available phosphorus & 0.45 & 0.42 & 0.38 \\
\hline Potassium & 0.68 & 0.57 & 0.50 \\
\hline Methionine & 0.50 & 0.48 & 0.50 \\
\hline Methionine+Cystine & 0.98 & 0.89 & 0.82 \\
\hline Lysine & 1.32 & 1.19 & 1.05 \\
\hline Arginine & 1.13 & 0.96 & 0.85 \\
\hline Threonine & 0.59 & 0.49 & 0.43 \\
\hline Valine & 0.73 & 0.62 & 0.54 \\
\hline ME, Kcal./Kg & 3008.0 & 3086.0 & 3167.0 \\
\hline
\end{tabular}

${ }^{*}$ Each $3.0 \mathrm{~kg}$ of premix supplies one ton of the diet with: Vit. A, 12000000 I.U; Vit. D, 2000000 I.U.; Vit. E, $40 g$; Vit. $K_{3}, 4 g$; Vit. $B_{1}, 3 g ;$ Vit. $B_{2}, 6 g$; Vit. $B_{6}, 4 g ;$ Vit. $B_{12}, 30 \mathrm{mg}$; Niacin, 30gm; Biotin, 80mg; Folic acid, 1.5g; Pantothinic acid, 12g; Zn, 70g; Mn, 70g; Fe, 40g; Cu, 10g; I, 1.5g; Co, 250mg; Se, 200mg; Choline, 350g and complete to $3.0 \mathrm{Kg}$ by calcium carbonate.

${ }^{* * *}$ According to NRC, 1994.

At the end of the experimental period ( 38 days), individual blood samples were taken from three birds of each treatment during the slaughter. The blood samples were collected into dry clean centrifuge tubes and centrifuged at $3000 \mathrm{rpm}$ for 20 minutes. The clear serum samples were carefully drawn and transferred to dry, clean, small glass bottles, and stored at $-20 \dot{\mathrm{C}}$ in a deep freezer until the time of chemical determinations. The biochemical characteristics of blood were determined colorimetrically using commercial kits. At the time of slaughter test, three samples of ileum content for each treatment were taken. Total microflora of ileum content was enumerated. The $\mathrm{pH}$ of intestinal contents was directly determined by $\mathrm{pH}$-meter. Commercial enzyme-linked immunosorbant assay (ELISA) kits were used for detection of antibodies against nucleoprotein and matrix against of Newcastle Disease Virus (NDV) and against of Avian Influenza Disease Virus (AIV). Hemagglutination-inhibition test titer regarded as positive if there is inhibition at serum dilution of 1/16 (4 $\log 2)$ using the ELISA technique.

To determine the economical efficiency for meat production, the amount of feed consumed during the entire experimental period was obtained and multiplied by the price of one $\mathrm{Kg}$ of each experimental diet which was estimated based upon local current prices at the experimental time. Statistical analysis of results was performed using the General Linear Models (GLM) procedure of the SPSS software (SPSS, 2007), according to the follow general model:

$$
Y_{i j}=\mu+T_{i}+e_{i j}
$$

Where: $Y_{\mathrm{ij}}$ : observed value, $\mu$ : overall mean, $\mathrm{T}_{\mathrm{i}}$ : treatment effect (i: 1 to 6$)$. $\mathrm{e}_{\mathrm{ij}}$ : random error.

Treatment means indicating significant differences $(\mathrm{P} \leq 0.01$ and $\mathrm{P} \leq 0.05)$ were tested using Duncan's multiple range test (Duncan, 1955). 


\section{RESULTS AND DISCUSSION}

\section{Productive performance:}

Productive performance of broiler chicks as affected by single or combined supplementation of EOs and MCFAs during the experimental periods is shown in Table (2). Significant differences in LBW, BWG, FCR, CPC, CCR and PI were found between chicks fed single or combined supplementation of EOs and MCFAs at 38 days of age. No significant response obtained for FI and GR was observed by feeding on single or combined supplementation of EOs and MCFAs.

As presented in Table 2, birds fed experimental diet $0.2 \mathrm{~g}$ EOs $/ \mathrm{kg}$ diet $+0.1 \%$ MCFAs had significantly higher LBW (2053.33g), BWG (1906.13g) and PI (38.50) than the control. The results indicated that LBW and BWG significantly increase with supplementation of single or combined supplementation of EOs and MCFAs of the diet than those fed control diet (Table 2). Similar effects were found by Cho et al. (2014) when phytogenic additives were included in the diet of chickens. Other studies showed improvements in LBW at 21 and 42 days when the chickens were fed peppermint, thyme leaves, and thymol with cinnamaldehyde or carvacrol (Tiihonen et al., 2010 and Hashemipour et al., 2016). Addition of a blend of EOs from basil, caraway, laurel, lemon, oregano, sage, tea and thyme in a diet meeting the nutrient requirements of broilers would improve the BWG with positive effects on FCR (Khattak et al., 2014).

Chicks fed combined supplementation of EOs and MCFAs experimental diet $(0.1 \mathrm{~g}$ EOs $/ \mathrm{kg}$ diet + $0.1 \%$ MCFAs) had best significantly FCR and CCR during the period from 7 to 38 days of age (1.71 and 5.29) compared with those fed the control diet.

Table (2): Effects of single or combined supplementation of essential oils (EOs) and medium chain fatty acids (MCFAs) to broiler diets on productive performance.

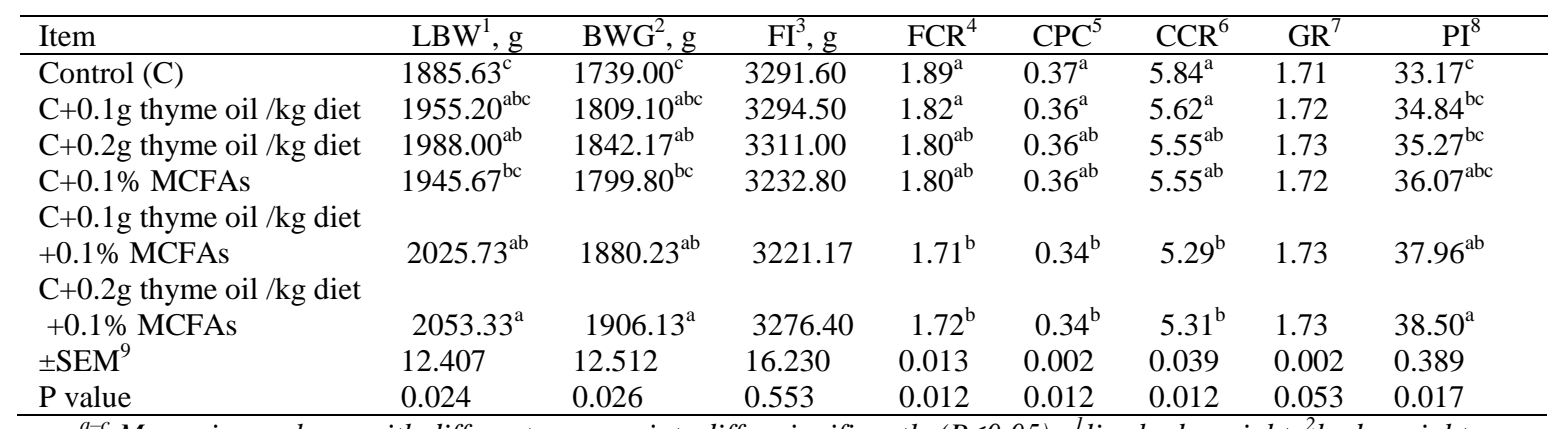

${ }^{a-c}$ Means in a column with different superscripts differ significantly $(P \leq 0.05) .{ }^{I}$ live body weight, ${ }^{2}$ body weight gain, ${ }^{3}$ feed intake, ${ }^{4}$ feed conversion, ${ }^{5}$ crude protein conversion, ${ }^{6}$ caloric conversion ratio, ${ }^{7}$ growth rate, ${ }^{8}$ performance index, ${ }^{9}$ Pooled SEM

Similar effects were reported by Cabuk et al. (2006) who found that broilers supplemented with a mixture of laurel, oregano, sage, citrus and anis EOs, or a mixture of EOs significantly improved FCR. In conclusion, there are improved in $\mathrm{CPC}$ and CCR of chicks which fed diets supplemented with EOs and MCFAs in a mixed form and not alone.

Generally our findings are partly congruent with that of Arcila-Lozano et al. (2004) and Bozin et al. (2006). They reported that the beneficial effect of labiatae family (thyme, rosemary and oregano) may be due to the phenolic compounds which considerably exhibit antimicrobial and antifungal activity. This activity may be due to thymol and carvacrol which are present in the EOs of thyme and oregano (Basilico and Basilico, 1999). These results were in line with findings of Radwan (2003) who demonstrated that, the use of $0.5 \%$ rosemary or thyme leaves in diets increased LBW and BWG and improved FCR of chicks. This improvement could be attributed to its content of EOs that have active components which have possess antimicrobial, antifungal and antioxidant activities; and accordingly could improve the bird utilization of dietary nutrients. In addition, Abdel-Latif et al. (2002) attributed the improvement in growth and FCR of chicks fed thyme leaves to the enhancement in thyroid activity 


\section{Omar et al.}

and the biological role of such medicinal plant in the metabolic functions and biosynthesis of hormones. These results agree with those obtained by Al-Sultan (2003) who found that the use of turmeric as feed additive at level $0.5 \%$ enhance the overall performance of broiler chickens. Moreno et al. (2006) reported that, carnosic acid and rosmarinic acid may be the main bioactive antimicrobial compounds present in rosemary. Dietary feeding of EOs extracted from herbs improved the secretion of digestive enzymes, so improved the digestibility of the feeds and improved the performance for broiler (Jang et al., 2004). Radwan and Abdel-Khalek (2007) indicated that the herb mixture of equal parts of sage, oregano and sweet basal at $0.5 \%$ supplementation level increased both of villi height, crypt depth and absorption area and improved growth and health of rabbits grown under high ambient temperature conditions. The increased BWG is due to the antioxidant activity of turmeric (Osawa et al., 1995); that stimulate protein synthesis by bird enzymatic system.

\section{Slaughter parameters:}

Data presented in Table (3) were shown the effects of single or combined supplementation of EOs and MCFAs to broiler diets on some slaughter parameters and immune organs as a percentage of LBW at 38 days of age. The results indicated no significant differences due to supplementation of EOs and MCFAs on slaughter parameters (liver, gizzard and heart), while abdominal fat $\%$, carcass weight after evisceration and dressing\% were recorded significantly affected. Chicks fed the control diet were significantly higher abdominal fat $\%$, carcass weight after evisceration and dressing\% than the other treated groups.

No significant differences were noticed in bursa $\%$ as affected by the treated groups in comparison with the control. There were significant differences for thymus and spleen $\%$ due to supplementation of EOs and MCFAs. Chicks fed experimental diet containing 0.2g EOs/kg diet+ 0.1\% MCFAs had significantly higher thymus and spleen $\%$ (0.60 and 0.16\%) compared with those fed MCFAs alone, EOs alone and the control respectively, while those fed control diet had the lower value $(0.41$ and $0.13 \%$ ).

Table (3): Effects of single or combined supplementation of essential oils (EOs) and medium chain fatty acids (MCFAs ) to broiler diets on some slaughter parameters\%.

\begin{tabular}{|c|c|c|c|c|c|c|c|c|c|c|c|}
\hline \multirow[b]{2}{*}{ Item } & \multirow[b]{2}{*}{ Liver } & \multirow[b]{2}{*}{ Gizzard } & \multirow[b]{2}{*}{ Heart } & \multirow{2}{*}{$\begin{array}{c}\text { Abdominal } \\
\text { Fat }\end{array}$} & \multirow{2}{*}{$\begin{array}{l}\text { Half } \\
\text { breast }\end{array}$} & \multirow{2}{*}{$\begin{array}{l}\text { Half } \\
\text { rear }\end{array}$} & \multirow{2}{*}{$\begin{array}{c}\text { Carcass } \\
\text { weight after } \\
\text { evisceration }\end{array}$} & \multirow{2}{*}{$\begin{array}{c}\text { Dressi } \\
\text { ng }\end{array}$} & \multicolumn{3}{|c|}{ Immune organs } \\
\hline & & & & & & & & & Bursa & $\begin{array}{c}\text { Thym } \\
\text { us }\end{array}$ & $\begin{array}{c}\text { Splee } \\
\mathrm{n}\end{array}$ \\
\hline Control (C) & 2.75 & 2.64 & 0.58 & $1.11^{\mathrm{a}}$ & 53.71 & 46.29 & $71.18^{\mathrm{a}}$ & $77.28^{\mathrm{a}}$ & 0.11 & $0.41^{\mathrm{c}}$ & $0.13^{\mathrm{c}}$ \\
\hline $\begin{array}{l}\mathrm{C}+0.1 \mathrm{~g} \text { thyme oil } \\
/ \mathrm{kg} \text { diet } \\
\mathrm{C}+0.2 \mathrm{~g} \text { thyme oil }\end{array}$ & 2.88 & 2.54 & 0.56 & $1.02^{\mathrm{ab}}$ & 52.93 & 47.07 & $62.44^{\mathrm{c}}$ & $68.56^{\mathrm{bc}}$ & 0.14 & $0.46^{\mathrm{c}}$ & $0.14^{\mathrm{bc}}$ \\
\hline$/ \mathrm{kg}$ diet & 2.66 & 2.43 & 0.57 & $0.96^{\mathrm{abc}}$ & 51.64 & 48.36 & $61.02^{\mathrm{c}}$ & $66.81^{\mathrm{c}}$ & 0.15 & $0.47^{\mathrm{c}}$ & $0.14^{\mathrm{bc}}$ \\
\hline $\begin{array}{l}\mathrm{C}+0.1 \% \text { MCFAs } \\
\mathrm{C}+0.1 \mathrm{~g} \text { thyme oil } \\
/ \mathrm{kg} \text { diet }\end{array}$ & 2.84 & 2.47 & $\cdots$ & $0.93^{\mathrm{bc}}$ & 55. 18 & 44.82 & $67.01^{\mathrm{b}}$ & $72.98^{\mathrm{ab}}$ & 0.16 & $0.50^{\mathrm{bc}}$ & $0.13^{\mathrm{c}}$ \\
\hline $\begin{array}{l}+0.1 \% \text { MCFAs } \\
\mathrm{C}+0.2 \mathrm{~g} \text { thyme oil } \\
/ \mathrm{kg} \text { diet }\end{array}$ & 2.72 & 2.47 & 0.57 & $0.89^{\mathrm{bc}}$ & 51.93 & 48.07 & $62.10^{\mathrm{c}}$ & $68.01^{\mathrm{c}}$ & 0.15 & $0.56^{\mathrm{ab}}$ & $0.15^{\mathrm{ab}}$ \\
\hline$+0.1 \%$ MCFAs & 2.72 & 2.55 & 0.57 & $0.84^{\mathrm{c}}$ & 52.96 & 47.04 & $62.37^{\mathrm{c}}$ & $68.36^{\mathrm{bc}}$ & 0.18 & $0.60^{\mathrm{a}}$ & $0.16^{\mathrm{a}}$ \\
\hline$\pm \mathrm{SEM}^{1}$ & 0.067 & 0.047 & 0.013 & 0.020 & 0.90 & 0.90 & 1.32 & 1.45 & 0.006 & 0.012 & 0.002 \\
\hline$P$ value & 0.928 & 0.804 & 0.884 & 0.021 & 0.147 & 0.147 & 0.001 & 0.002 & 0.069 & 0.005 & 0.007 \\
\hline
\end{tabular}

As in our results, Lee et al. (2003) found that broiler chickens given dietary carvacrol and thymol at $200 \mathrm{mg} / \mathrm{kg}$ diet showed no differences in the relative weight of the liver compared with the control birds. In this respect, Al-Sultan (2003) reported that, higher spleen weight index was observed in birds received feed contained $1.0 \%$ tumeric. While Ali et al., (2007) reported that hens fed thyme or anise had no significant effect on carcass parameters and internal organ.

Also Khaligh et al. (2011) reported that supplementation of broiler diets with medicinal plant blends did not altered liver and gizzard weight as compared to control birds. Habibi et al. (2014) reported that broiler carcass relative weight was not affected by the inclusion of 0.75 and $1.5 \%$ ginger root powder in the diet that consistent with present results. 


\section{Blood parameters:}

Results presented in Tables (4 and 5) show the effect of dietary single or combined supplementation of EOs and MCFAs on some blood parameters.

Concerning the treatment effect on blood constituents, the results indicated no significant differences due to supplementation of single or combined supplementation of EOs and MCFAs except, white blood cells (WBCs), lymphocyte and eosinophiles, which were significantly affected. Chicks fed diet supplemented with $0.2 \mathrm{~g}$ EOs $/ \mathrm{kg}$ diet+ $0.1 \%$ MCFAs had higher value of lymphocyte, while those fed the control diet had lower values, the remaining groups recorded intermediate values (Table 4). Chicks fed 0.1\% MCFAs diet showed the higher value of eosinophiles (7.33\%) compared with those fed $0.2 \mathrm{~g}$ EOs $/ \mathrm{kg}$ diet+ $0.1 \%$ MCFAs or $0.1 \mathrm{~g}$ EOs $/ \mathrm{kg}$ diet which were the lower values (3.67 and $3.33 \%$, respectively).

Table (4): Effects of single or combined supplementation of essential oils (EOs) and medium chain fatty acids (MCFAs ) to broiler diets on some blood parameters.

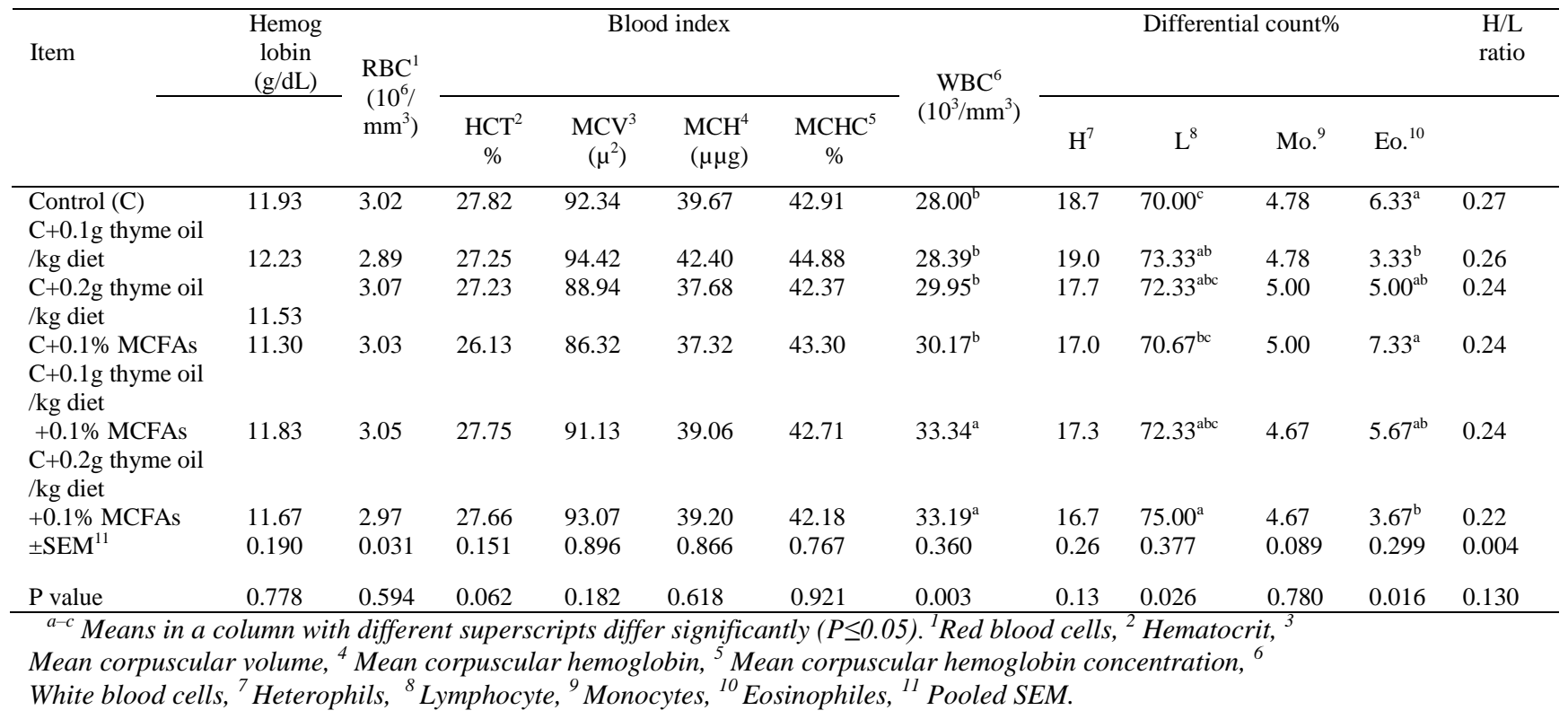

As shown in Table (5), the level of serum ALT, AST, total lipids, TG and total cholesterol had significantly affected $(\mathrm{P} \leq 0.05)$ in chicks fed diets supplemented with EOs and MCFAs compared with the control diet. Chicks fed diet $0.2 \mathrm{~g}$ EOs $/ \mathrm{kg}$ diet+ $0.1 \%$ MCFAs showed the lower values of ALT and AST as compared with those fed the control diet and some other treatments which were the higher values. Chicks fed all experimental treatments had lower values of total lipids, TG and total cholesterol as compared with the control diet (differences between control (the higher value) and those fed diet supplemented with $0.1 \mathrm{~g}$ thyme oil $/ \mathrm{kg}$ diet were not significant (Table 5). 
Table (5): Effects of single or combined supplementation of essential oils (EOs) and medium chain fatty acids (MCFAs ) to broiler diets on plasma parameters and lipids profiles.

\begin{tabular}{|c|c|c|c|c|c|c|c|c|c|}
\hline \multirow{2}{*}{ Item } & \multirow{2}{*}{$\begin{array}{c}\text { Total } \\
\text { protein } \\
\mathrm{g} / \mathrm{dL}\end{array}$} & \multirow{2}{*}{$\begin{array}{l}\text { Albumin } \\
\text { (A) g/dL }\end{array}$} & \multirow{2}{*}{$\begin{array}{l}\text { Globulin } \\
\text { (G) g/dL }\end{array}$} & \multirow{2}{*}{$\mathrm{A} / \mathrm{G}$} & \multirow{2}{*}{$\begin{array}{l}\mathrm{ALT}^{1} \\
(\mathrm{U} / \mathrm{L})\end{array}$} & \multirow{2}{*}{$\begin{array}{l}\mathrm{AST}^{2} \\
(\mathrm{U} / \mathrm{L})\end{array}$} & \multicolumn{3}{|c|}{ Lipids profiles (mg/dl) } \\
\hline & & & & & & & $\begin{array}{l}\text { Total } \\
\text { lipids }\end{array}$ & $\begin{array}{c}\text { Tri- } \\
\text { glycerides }\end{array}$ & $\begin{array}{c}\text { Total } \\
\text { cholesterol }\end{array}$ \\
\hline Control (C) & 2.93 & 1.30 & $1.63^{\mathrm{b}}$ & 0.79 & $27.67^{\mathrm{a}}$ & $159.33^{\mathrm{a}}$ & $376.33^{\mathrm{a}}$ & $93.00^{\mathrm{a}}$ & $180.67^{\mathrm{a}}$ \\
\hline $\mathrm{C}+0.1 \mathrm{~g}$ thyme oil $/ \mathrm{kg}$ diet & 3.43 & 1.33 & $2.10^{\mathrm{a}}$ & 0.64 & $27.00^{\mathrm{ab}}$ & $158.00^{\mathrm{a}}$ & $359.00^{\mathrm{a}}$ & $91.00^{\mathrm{ab}}$ & $179.67^{\mathrm{a}}$ \\
\hline $\mathrm{C}+0.2 \mathrm{~g}$ thyme oil $/ \mathrm{kg}$ diet & 3.57 & 1.37 & $2.20^{\mathrm{a}}$ & 0.62 & $23.67^{\mathrm{bc}}$ & $147.67^{\mathrm{ab}}$ & $309.67^{\mathrm{b}}$ & $78.67^{\text {bcd }}$ & $162.00^{\mathrm{b}}$ \\
\hline $\mathrm{C}+0.1 \%$ MCFAs & 3.43 & 1.30 & $2.13^{\mathrm{a}}$ & 0.63 & $24.00^{\mathrm{bc}}$ & $138.00^{\mathrm{b}}$ & $326.00^{\mathrm{b}}$ & $87.67^{\mathrm{abc}}$ & $157.67^{\mathrm{b}}$ \\
\hline \multicolumn{10}{|l|}{$\mathrm{C}+0.1 \mathrm{~g}$ thyme oil $/ \mathrm{kg}$ diet } \\
\hline$+0.1 \%$ MCFAs & 3.23 & 1.23 & $2.00^{\mathrm{ab}}$ & 0.62 & $22.67^{\mathrm{c}}$ & $141.00^{\mathrm{ab}}$ & $309.33^{\mathrm{b}}$ & $75.33^{\mathrm{cd}}$ & $159.33^{\mathrm{b}}$ \\
\hline \multicolumn{10}{|l|}{$\mathrm{C}+0.2 \mathrm{~g}$ thyme oil $/ \mathrm{kg}$ diet } \\
\hline$+0.1 \%$ MCFAs & 3.73 & 1.33 & $2.40^{\mathrm{a}}$ & 0.55 & $22.33^{\mathrm{c}}$ & $133.00^{\mathrm{b}}$ & $303.00^{\mathrm{b}}$ & $72.67^{\mathrm{d}}$ & $155.67^{\mathrm{b}}$ \\
\hline$\pm \mathrm{SEM}^{3}$ & 0.075 & 0.046 & 0.055 & 0.026 & 0.434 & 2.321 & 2.922 & 1.681 & 1.820 \\
\hline$P$ value & 0.108 & 0.973 & 0.032 & 0.256 & 0.016 & 0.032 & 0.000 & 0.017 & 0.004 \\
\hline
\end{tabular}

${ }^{a-d}$ Means in a column with different superscripts differ significantly $(P \leq 0.05)$. ${ }^{I}$ Alanine aminotransferase, ${ }^{2}$ Aspartate aminotransferase, ${ }^{3}$ Pooled SEM

In accordance with the results of the present experiment, Radwan et al. (2008), found that supplementation of thyme at $1.0 \%$ significantly decreased total lipid, in comparison to the control, while total cholesterol and LDL-cholesterol decreased insignificantly compared to control group. These results agree to a large extent with those obtained by Ali et al. (2007) who found that addition of thyme to hen's diets significantly decreased plasma HDL, total cholesterol, triglyceride and total lipid. In this respect, Najafi and Taherpour (2014) reported that the significant improvement in lymphocyte ratio with oil extract supplementation may be due to herbal oils such as ginger oil increase immunoglobulins levels in the blood as well as the ability to destroy microbial cells by leukocytes due to terpinolen. Radwan (2003) reported that the high level of iron in thyme leaves (743 ppm) which may affect the transport of oxygen needed for hemoglobin synthesis in blood. This improvement may be due to the antioxidant activity of EOs components, thyme oil (Hertrampf, 2001). Ibrahim et al. (2000) found that, RBCs, hemoglobin and the packed cell volume for rabbits fed diet with $0.5 \%$ thyme were significant increased. Laying hens fed diet supplemented with $100 \mathrm{mg}$ EOs $+500 \mathrm{mg}$ mannan oligosaccharide (MOS/kg) diet had significant higher values of HDL cholesterol, total antioxidant capacity and GSH-Px activity in plasma. While, those fed control diet had higher values of total lipid, triglycerides and LDL cholesterol in plasma (Emam et al., 2016).

\section{Intestinal microflora:}

Data presented in Table (6) indicate the effects single or combined supplementation of EOs and MCFAs to broiler diets on intestinal $\mathrm{pH}$, bacterial count and immune response to Avian Influenza virus (AIV) and ND. Single or combined supplementation of EOs and MCFAs addition and dietary treatments had significantly affected intestinal $\mathrm{pH}$, bacterial count and immune response to AIV and NDV. Chicks fed diet containing 0.1g EOs/kg diet had higher intestinal $\mathrm{pH}$ (6.56), while, Chicks fed diet containing $0.1 \%$ MCFAs resulted in the lower intestinal $\mathrm{pH}$ values (6.10) and higher value of total count (10.95) than the control and the other treated groups. 
Table (6): Effects of single or combined supplementation of essential oils (EOs) and medium chain fatty acids (MCFAs) to broiler diets bacterial count and immune response to Newcastle disease virus (NDV) and avian influenza virus (AIV).

\begin{tabular}{|c|c|c|c|c|c|c|}
\hline \multirow{2}{*}{ Item } & \multirow{2}{*}{$\begin{array}{c}\text { Intestinal } \\
\text { pH }\end{array}$} & \multicolumn{3}{|c|}{ Bacterial count } & \multicolumn{2}{|c|}{ Titration against } \\
\hline & & Total Count & E.coli $10 * 4$ & lactobacillus & NDV & AIV \\
\hline Control (C) & $6.54^{\mathrm{a}}$ & $10.66^{\mathrm{b}}$ & $4.65^{\mathrm{a}}$ & $5.03^{\mathrm{d}}$ & $7.33^{\mathrm{c}}$ & $7.00^{\mathrm{c}}$ \\
\hline $\mathrm{C}+0.1 \mathrm{~g}$ thyme oil $/ \mathrm{kg}$ diet & $6.56^{\mathrm{a}}$ & $10.73^{\mathrm{b}}$ & $4.55^{\mathrm{a}}$ & $5.10^{\mathrm{cd}}$ & $7.67^{\mathrm{bc}}$ & $7.33^{\mathrm{bc}}$ \\
\hline $\mathrm{C}+0.2 \mathrm{~g}$ thyme oil $/ \mathrm{kg}$ diet & $6.49^{\mathrm{a}}$ & $10.61^{\mathrm{b}}$ & $4.56^{\mathrm{a}}$ & $5.22^{\mathrm{c}}$ & $8.33^{\mathrm{abc}}$ & $8.33^{\mathrm{ab}}$ \\
\hline $\mathrm{C}+0.1 \%$ MCFAs & $6.10^{\mathrm{b}}$ & $10.95^{\mathrm{a}}$ & $4.00^{\mathrm{b}}$ & $5.65^{\mathrm{b}}$ & $7.67^{\mathrm{bc}}$ & $7.33^{\mathrm{bc}}$ \\
\hline $\mathrm{C}+0.1 \mathrm{~g}$ thyme oil $/ \mathrm{kg}$ diet & & & & & & \\
\hline$+0.1 \%$ MCFAs & $6.42^{\mathrm{a}}$ & $10.58^{b}$ & $3.90^{\mathrm{bc}}$ & $5.70^{\mathrm{ab}}$ & $8.67^{\mathrm{ab}}$ & $8.67^{\mathrm{a}}$ \\
\hline $\mathrm{C}+0.2 \mathrm{~g}$ thyme oil $/ \mathrm{kg}$ diet & & & & & & \\
\hline$+0.1 \%$ MCFAs & $6.36^{\mathrm{a}}$ & $10.65^{\mathrm{b}}$ & $3.80^{\mathrm{c}}$ & $5.83^{\mathrm{a}}$ & $9.00^{\mathrm{a}}$ & $8.67^{\mathrm{a}}$ \\
\hline$\pm \mathrm{SEM}^{1}$ & 0.026 & 0.023 & 0.016 & 0.019 & 0.124 & 0.157 \\
\hline$P$ value & 0.002 & 0.008 & 0.000 & 0.000 & 0.014 & 0.027 \\
\hline
\end{tabular}

E. coli counts were reduced significantly by feeding diet supplemented with MCFAs alone or in a mixed form with EOs compared with the control or those fed diet supplemented with EOs alone. The lower value was obtained for chicks fed diet containing $0.2 \mathrm{~g}$ EOs $/ \mathrm{kg}$ diet+ $0.1 \%$ MCFAs (3.80) followed by chicks fed diet supplemented with $0.1 \mathrm{~g}$ EOs $/ \mathrm{kg}$ diet+ $0.1 \%$ MCFAs (3.90). The higher value was obtained for chicks fed control diet (4.65) then chicks fed diet supplemented with $0.2 \mathrm{~g}$ EOs $/ \mathrm{kg}$ diet (4.56). Chicks fed $0.2 \mathrm{~g}$ EOs $/ \mathrm{kg}$ diet $+0.1 \%$ MCFAs showed significantly higher lactobacillus count (5.83), while the lower value was observed in chicks fed the control diet (5.03), as shown in Table (6).

These results are in good agreement with that of (Al-Kassie, 2010) who studied the effects of the addition of different percent levels of thyme and cinnamon on the intestinal microbial balance on broiler chicks, that include different region of gastro intestinal tract of digestive system (crop, jejunum and large intestine) at six-weeks old of experiment, he found that the two additives $(0.5 \%, 1 \%$ thyme and $1 \%$ cinnamon) recorded a significant decrease at of total bacteria count (CFU/gm) for in crop, jejunum and large intestine. Where they pointed out the positive effect of thyme additive in decreasing E. coli in various of gastrointestinal tract in order to improve the animal health. Also, Spais et al. (2002) found that a commercial feed additive containing herb extracts and organic acids exerts a growth promoting effect comparable to that of flavomycin. Moreover, the positive effects of these additives may be explain based on herbal plants and herbal extracts that have appetite effect (AbouSekken et al., 2007) and increased production of digestive enzymes through enhanced liver functions (Williams and Losa, 2001) or antimicrobial activity against pathogenic bacteria which improve the efficiency of feed utilization (Ghazalah and Ibrahim, 1996). However, Jamroz et al. (2003) and Mitsch et al. (2004) determined that plant extract (carvacrol, cinnamaldehyde and capsaicin) reduced the total E. coli and can control Clostridium perfringens colonization in the intestine and feces of broiler chickens. Aantibacterial, anticoccidial, antifungal and antioxidant effects of capsaicin (Chevallier, 1996) and thyme oil (Hertrampf, 2001) were reported. El-Faham et al. (2015) showed that the growth promoting effect of thyme oil on beneficial bacteria (lactic acid) and its growth inhibiting effect on harmful bacteria (coli-form) in beneficial in regulating intestinal micro-ecological balance. The beneficial effect of thyme oil can confer protection against potential enter pathogenic bacteria and prevent or cure intestinal diseases.

The interpretation of these data results reflex the complexity of micro flora development with the age in broiler synchronized with the addition of thyme and its active ingredients (thyme and cervical), inhibition of pathogenic bacteria such as E. coil 0157:H7, Sal., typhimurium, Shigella Sonnei and Bacillus Subtitles (Fan and Chen, 2001). Coli form bacteria is an indicator tool for intestinal performance, so that thyme and cinnamon on with complex mechanisms affect pathogenic bacteria by changing cell wall bacterial permeability leading to pore formation and osmotic shock and leakage of cytoplasm and its active contents out-side the cell leading to death of them (Lee et al., 2004), the antimicrobial effect thymol on these bactin played on vital membrane ions of potassium and hydrogen equilibrium pumps (Bolukbasi and Erhan, 2007). 
Data revealed that there were significant differences of AIV and NDV values among groups, the worst values of immune response to AIV and NDV were observed for the control (7.00 and 7.33, respectively), while the best of immune response to AIV and NDV values were observed by feeding on combined supplementation of $0.2 \mathrm{~g}$ EOs $/ \mathrm{kg}$ diet $+0.1 \%$ MCFAs (8.67 and 9.00 respectively), and other treatments showed an intermediate values (Table 6).

In this respect, The anti-oxidation properties of some herbs bioactive (extracts and EOs) have been thought to have a role in the development of immune response in birds via protecting cells from oxidative damage and enhancing the function and proliferation of these cells ( Ma et al., 2005). However, Ozek et al. (2011) demonstrated that an EOs blend was not effective in improving the humoral immune response of layer hens as measured serum IBDV, NDV and IBV titers. Also, Bozkurt et al. (2012) found that none of MOS or EOs, whether yeast-based or botanical originated, could support the immune system and boost antibody titers. Laying hens fed diet supplemented with $100 \mathrm{mg}$ EOs $+500 \mathrm{mg} \mathrm{MOS} / \mathrm{kg}$ diet had significant higher value of immune response to antibody titer of AIV. While, those fed control diet had significant lower value of AIV. No significant differences of NDV among treatment groups (Emam et al., 2016).

\section{Economic efficiency (EEf):}

Results in Table (7) showed that economic efficiency (EEf) values during the period from 7 to 38 days

Table (7): Effects of single or combined supplementation of essential oils (EOs) and medium chain fatty acids (MCFAs) to broiler diets on economical efficiency (EEf).

\begin{tabular}{|c|c|c|c|c|c|c|}
\hline \multirow[b]{2}{*}{ Item } & \multicolumn{6}{|c|}{ Treatment } \\
\hline & $\begin{array}{l}\text { Control } \\
\text { (C) }\end{array}$ & $\begin{array}{l}\mathrm{C}+0.1 \mathrm{~g} \\
\text { thyme oil } \\
/ \mathrm{kg} \text { diet }\end{array}$ & $\begin{array}{l}\mathrm{C}+0.2 \mathrm{~g} \\
\text { thyme oil } \\
/ \mathrm{kg} \text { diet }\end{array}$ & $\begin{array}{l}\mathrm{C}+0.1 \% \\
\text { MCFAs }\end{array}$ & $\begin{array}{l}\text { C+0.1g } \\
\text { thyme oil } \\
/ \mathrm{kg} \text { diet } \\
+0.1 \% \\
\text { MCFAs }\end{array}$ & $\begin{array}{c}\mathrm{C}+0.2 \mathrm{~g} \\
\text { thyme oil } \\
/ \mathrm{kg} \text { diet } \\
+0.1 \% \\
\text { MCFAs }\end{array}$ \\
\hline$a_{1}$ & 0.3897 & 0.3923 & 0.3923 & 0.3987 & 0.3862 & 0.3837 \\
\hline$b_{1}$ & 389.20 & 393.20 & 397.20 & 396.20 & 400.20 & 404.20 \\
\hline$a_{1} \times b_{1}=c_{1}$ & 151.66 & 154.26 & 155.83 & 157.95 & 154.55 & 155.10 \\
\hline $\mathrm{a}_{2}$ & 0.5627 & 0.5355 & 0.5287 & 0.4941 & 0.5273 & 0.5620 \\
\hline $\mathrm{b}_{2}$ & 381.20 & 385.20 & 389.20 & 388.20 & 392.20 & 396.20 \\
\hline$a_{2} \times b_{2}=c_{2}$ & 214.50 & 206.28 & 205.76 & 191.82 & 206.82 & 222.66 \\
\hline$a_{3}$ & 1.1576 & 1.1570 & 1.1540 & 1.1493 & 1.1450 & 1.1157 \\
\hline $\mathrm{b}_{3}$ & 369.50 & 373.50 & 377.50 & 376.50 & 380.50 & 384.50 \\
\hline$a_{3} \times b_{3}=c_{3}$ & 427.72 & 432.14 & 435.64 & 432.72 & 435.67 & 428.98 \\
\hline $\mathrm{a}_{4}$ & 1.1817 & 1.2097 & 1.2360 & 1.1907 & 1.1627 & 1.2150 \\
\hline $\mathrm{b}_{4}$ & 369.50 & 373.50 & 377.50 & 376.50 & 380.50 & 384.50 \\
\hline $\mathrm{a}_{4} \times \mathrm{b}_{4}=\mathrm{c}_{4}$ & 436.63 & 451.81 & 466.59 & 448.29 & 442.40 & 467.17 \\
\hline$\left(c_{1}+c_{2}+c_{3}+c_{4}\right)=c_{\text {total }}$ & 1230.5 & 1244.5 & 1263.8 & 1230.8 & 1239.4 & 1273.9 \\
\hline D & 1.8856 & 1.9552 & 1.9880 & 1.9457 & 2.0257 & 2.0533 \\
\hline $\mathrm{E}$ & 1700.0 & 1700.0 & 1700.0 & 1700.0 & 1700.0 & 1700.0 \\
\hline $\mathrm{d} \times \mathrm{e}=\mathrm{f}$ & 3205.6 & 3323.8 & 3379.6 & 3307.6 & 3443.7 & 3490.6 \\
\hline $\mathrm{f}-\mathrm{c}_{\text {total }}=\mathrm{g}$ & 1975.1 & 2079.4 & 2115.8 & 2076.9 & 2204.3 & 2216.8 \\
\hline $\begin{array}{l}\text { Economical } \\
\text { efficiency }\left(\mathrm{g} / \mathrm{c}_{\text {total }}\right)\end{array}$ & 1.6051 & 1.6708 & 1.6741 & 1.6874 & 1.7785 & 1.7401 \\
\hline Relative efficiency (r) & 100.00 & 104.10 & 104.30 & 105.13 & 110.80 & 108.41 \\
\hline
\end{tabular}

$a_{1,} a_{2}, a_{3}$ and $a_{4} \ldots . .$. average feed intake (Kg/bird) during the periods of starter, grower, finisherl and finisher 2, respectively. $b_{1}, b_{2}, b_{3}$ and $b_{4} \ldots \ldots$ price / Kg feed (P.T.) during the periods of starter, grower, finisher 1 and finisher 2, respectively (based on average local market price of diets during the experimental time).

$c_{1}, c_{2}, c_{3}$ and $c_{4} \ldots \ldots$.... feed cost (P.T.) during the periods of starter, grower, finisher 1 and finisher 2, respectively.

Total feed cost (P.T. $)=c_{\text {total }}=\left(c_{1}+c_{2}+c_{3}+c_{4}\right)$ Average $L B W(K g /$ bird $) \quad d$

Price / Kg live weight (P.T.) e e.........(according to the local market price at the experimental time).

Total revenue $(P . T)=.d x e=f$. Net revenue $(P . T)=.f-c_{\text {total }}=g$

Economical efficiency $=\left(g / c_{\text {total }}\right)$................(net revenue per unit feed cost $)$.

Relative efficiency r....(assuming that economical efficiency of the control group (1) equals 100). 
of age improved in chicks fed diet containing single or combined supplementation of EOs and MCFAs as compared with those fed the control diet. Chicks fed with $0.1 \mathrm{~g}$ EOs $/ \mathrm{kg}$ diet $+0.1 \%$ MCFAs had the highest economic and relative efficiency values being (1.78 and $110.8 \%)$, followed with $0.2 \mathrm{~g}$ EOs $/ \mathrm{kg}$ diet $+0.1 \%$ MCFAs (1.74 and $108.41 \%)$.

\section{CONCLUSION}

Generally, it could be concluded that chicks fed diet contained $1 \mathrm{~g}$ aromabiotic $/ \mathrm{kg}$ diet $+100 \mathrm{~g}$ thyme oil/kg diet had the better LBW, FCR, PI, blood parameters, microbial load and economical efficiency.

\section{REFERENCES}

AOAC (2016). Association of Official Analytical Chemists, Official Methods of Analysis. 20th Edition, Washington, D.C, USA, online.

Abdel-Latif, S. A., F. A. Ahmed and A. M. El-Kaiaty (2002). Effect of feeding dietary thyme, black cumin, dianthus and fennel on productive and some metabolic responses of growing Japanese quail. Egypt. Poult. Sci., 22:109-125.

Abou-Sekken, M. S. M., K.M.E. Moustafa and T. Sc. Elalfy (2007). Effect of fennel, thyme and probiotic as feed additives on the performance and the microbial content of the intestine of Muscovy ducks. Egypt. Poult. Sci., 27: 1009-1029.

Adaszynska-Skwirzynska, M. and D. Szczerbinska (2018). Use of essential oils in broiler chicken production - a review. Annals of Anim. Sci., 17: 317-335.

Ali, M. N., M. S. Hassan and F. A. Abd El-Ghany (2007). Effect of strain, type of natural antioxidant and sulphate ion on productive, physiological and hatching performance of native laying hens. Int. J. Poult. Sci., 6: 539-554.

Al-Kassie, G. A. M. (2010). The effect of thyme and cinnamon on the microbial balance in gastro intestinal tract on broiler chicks. Int. J. Poult. Sci., 5: 495-498.

Al-Sultan, S. I. (2003). The effect of curcuma longa (Tumeric) on overall performance of broiler chickens. Int. J. Poult. Sci., 2: 351-353.

Arcila-Lozano, C. C., G. Loarca-Pina, S. Lecona-Uribe and E. Gonzalez de Mejia (2004). Oregano: Properties, composition and biological activity. Arch Latinoam Nutr., 54: 100-111.

Basilico, M. Z. and J. C. Basilico (1999). Inhibitory effect of some spice essential oils on Aspergillus ochraceus NRRL3174 growth and ochratoxin A production. Lrtt. Appl. Microbiol., 29: 238-241.

Bolukbasi, S. and M. Erhan (2007). Effect of dietary thyme (Thymus vulgaris) on laying hens performance and Escherichia coli (E. coli) concentration in feces. Atatürk University, the Faculty of Agric., Department of Anim. Sci., 25240, Erzurum, Turkey.

Bozin, B., N. Mimica-Dukic, N. Simin and G. Anackov (2006). Characterization of the volatile composition of essential oils of some lamiaceae spices and the antimicrobial and activities of the entire oils, 2006. J. Agric. Food Chem., 8, 54: 1822-1828.

Bozkurt, M., K. Kucukyilmaz, A. U. Catli, M. Cinar, E. Bintas and F. Covent (2012). Performance, egg quality, and immune response of laying hens fed diets supplemented with mannan oligosaccharide or an essential oil mixture under moderate and hot environmental conditions. Poult. Sci., 91:1379-1386. 


\section{Omar et al.}

Cabuk, M., M. Bozkurt, A. Alcicek, Y. Akbap and K. Kucukyllmaz (2006). Effect of an herbal essential oil mixture on growth and internal organ weight of broilers from young and old breeder flocks. South African J. of Anim. Sci., 36: 135-141.

Chevallier, A. (1996). The encyclopedia of medicinal plants. DK publishing Inc, USA.

Cho, J. H., I. H. Kim and I. J. Kim (2014). Effects of phytogenic feed additive on growth performance, digestibility, blood metabolites, intestinal microbiota, meat color and relative organ weight after oral challenge with Clostridium perfringens in broilers. Livestock Sci., 160: 82-88.

Del Alamo, A.G., J. De Los Mozos, J.T.P. Van Dam and P.P. De Ayala (2007). The use of short and medium chain fatty acids as an alternative to antibiotic growth promoters in broilers infected with malabsorption syndrome. Proceedings of the $16^{\text {th }}$ European Symposium on Poultry Nutrition; Strasbourg, France. p. 317-320.

Dewi, G., D. V. T. Nair, S. Manjankattil, C. Peichel, J. Langlie and A. K. Johny (2018). Effect of lemongrass essential oil on Salmonella Heidelberg colonization in commercial broiler chickens. Poult. Sci. Association 107 ${ }^{\text {th }}$ Annual Meeting. San Antonio, TX. Poult. Sci., 97 (E-Suppl. 1): 214.

Dierick, N., J. Decuypere, K. Molly, E. Van Beek and E.Vanderbeke (2002). The combined use of triacylglycerols containing medium-chain fatty acids (MCFAs) and exogenous lipolytic enzymes as an alternative for nutritional antibiotics in piglet nutrition: I. In vitro screening of the release of MCFAs from selected fat sources by selected exogenous lipolytic enzymes under simulated pig gastric conditions and their effects on the gut flora of piglets. Livest Prod Sci., 75:129-142.

Ding, S. and M. Lilburn (1997). Inclusion of coconut oil in diets for Turkey breeders and its effects on embryonic yolk and liver fatty acids. Poult. Sci., 76:1714-1721.

Duncan, D. B. (1955). Multiple range and multiple F tests. Biometrics, 11:1-42.

El-Faham, A. I., A. M. H. Ahmed and M. H. S. El-Sanhoury (2015). Thyme leaves or its extracted oil for enhancing productive and physiological status of broiler chickens. Egypt. Poult. Sci., 35: 215236.

Emam, R.M.S., A.M.R. Osman, A.M.M. Abdelsalam and M.M.M Aly (2016). Effect of dietary supplementation with an essential oils blend and mannan oligosaccharide on 2-the reproductive performance, egg quality and blood parameters of golden montazah layers at late phase of egg production. Egyptian J. Nutr. and Feeds (2015), 18 (3): 497-513.

Fan, M. and J. Chen (2001). Studies on antimicrobial activity of extracts from thyme. Wei Sheng Wu Xue Salmonella Bao., 41: 499-504.

Ghazalah, A. A. and F. A. A. Ibrahim (1996). The possibility of using some edible and aromatic oils in the nutrition of Muscovi ducks. Egypt. Poult. Sci., 16: 305-328.

Habibi, R., G. H. Sadeghi and A. Karimi (2014). Effect of different concentrations of ginger root powder and its essential oil on growth performance, serum metabolites and antioxidant status in broiler chicks under heat stress. Br. Poult. Sci., 55(2): 228-237.

Hashemipour, H., V. Khaksar, L. A. Rubio, T. Veldkamp and van M. M. Krimpen (2016). Effect of feed supplementation with a thymol plus carvacrol mixture, in combination or not with an NSP degrading enzyme, on productive and physiological parameters of broilers fed on wheat-based diets. Anim. Feed Sci. and Technology. 211:117-131.

Hermans, D., A. Martel, K. Van Deun, M. Verlinden, F. Van Immerseel, A. Garmyn, W. Messens, M. Heyndrickx, F. Haesebrouck and F. Pasmans (2010). Intestinal mucus protects campylobacter jejuni in the ceca of colonized broiler chickens against the bactericidal effects of medium-chain fatty acids. Poult. Sci., 89:1144-1155

Hertrampf, J. W. (2001). Alternative antibacterial performance promoters. Poult. Inter, 40: 50-52.

Ibrahim, Sh., A. M., A. A. El-Ghamry and G. M. El-Mallah (2000). Effect of some medicinal plants of Lablatae family as feed additives on growth and metabolic changes of rabbits. Egypt. J. Rabbit Sci., 10: 105-120. 
Jamroz, D., T. J. Wertlecki, J. Orda, A. Wiliczkiewicz and J. Skorupinska (2003). Influence of phtogenic extracts on gut microbial status in chickens. In: Proc. 14th European Symposium on Poult. Nutr., August, Lillehammer, Norway, p. 176.

Jang, I. S., Y. H. Ko, H. Y. Yang, J. S. Ha, J. Y. Kim, J. Y. Kim, S.Y. Kang, D. H. Yoo, D .S. Nam, D. H. Kim and C.Y. Lee (2004). Influence of essential oil components on growth performance and the functional activity of the pancreas and small intestine in broiler chickens. Asian - Aust. J. Anim. Sci., 17: 394-400.

Khaligh F., G. Sadeghi, A. Karimi and A. Vaziry (2011). Evaluation of different medicinal plants blends in diets for broiler chickens. J. Med. Plants. Res., 5: 1971-1977.

Khan, S. H. (2014). The use of green tea (Camellia sinensis) as a phytogenic substance in poultry diets. Onderstepoort. J. of Veterinary Research 81(1): Art. \#706, 8 pages. http://dx.doi. org/10.4102/ojvr.v81i2.706

Khattak, F., A. Ronchi, P. Castelli and N. Sparks (2014). Effects of natural blend of essential oil on growth performance, blood biochemistry, cecal morphology, and carcass quality of broiler chickens. Poult. Sci., 93: 132-137.

Kollanoor Johny, A. and K. Venkitanarayanan (2017). Chapter 17- Preharvest Food Safety-Potential Use of Plant-Derived Compounds in Layer Chickens. In Producing Safe Eggs. Ricke, S. and Gast, R. (Eds.) Academic Press, New York, Pages 347 -372.

Lee, K. W., H. Everts and A. C. Beynen (2004). Essential oils in broiler nutrition. Int. J. Poult. Sci., 3: 738-752.

Lee, K. W., H. Everts, H. J. Kappert, K. H. Yeom and A. C. Beynen, (2003). Dietary carvacrol lowers body weight gain but improves feed conversion in female broiler chickens. J. Appl. Poult. Res., 12: 394-399.

Leeson, S. (2008). Predictions for commercial poultry nutrition. J. Appl. Poult. Res., 17: 315-322.

Ma, D., A. Shan, Z. Chen, J. Du, K. Song, J. Li and Q. Xu (2005). Effect of Ligustrum lucidum and Schisandra chinensis on the egg production, antioxidant status and immunity of laying hens during heat stress. Arch. Anim. Nutr., 59:439-447.

Menten, J. F. M. (2001). Aditivos alternativos na nutricao de aves: probioticos e prebioticos. In: Reuniao Anual Da Sociedade Brasileira De Zootecnia, 38, 2001, Piracicaba. Anais. Piracicaba, SBZ, p.141-157.

Mitsch, P., K. Zitterl-Eglseer, B. Kohler, C. Gabler, R. Losa and I. Zimpernik (2004). The effect of two different blends of essential oil components on the proliferation of Clostridium perfringens in the intestines of broiler chickens. Poult. Sci., 83: 669-675.

Moreno, S., T. Scheyer, C. S. Romano and A. A. Vojnov (2006). Antioxidant and antimicrobial activities of rosemary extracts linked to their polyphenol composition. Free Radic. Res., 40: 223231.

Mroz, Z. (2005). Organic acids as potential alternatives to antibiotic growth promoters for pigs. Adv. Pork Prod, 16:169-182.

Nair, D. V. T. (2019). The role of essential oils and other botanicals in optimizing gut function in poultry. In improving gut function in poultry. Ricke, S. (Ed.). Burleigh Dodds Science Publishing, Cambridge, UK (Accepted).

Najafi, S. and K. Taherpour (2014). Effects of dietary ginger (Zingiber Ofjicinale), cinnamon (Cinnamomum), synbiotic and antibiotic supplementation on performance of broilers. J. Anim. Sci., 4: 658-667.

NRC (1994). National Research Council. Nutrient Requirements of Poultry. 9th revised edition. National Academy Press. Washington, D.C., USA.

North, M. O. (1981). Commercial Chicken Production Manual, 2nd Edition. AVI Publishing Company Inc, USA. 


\section{Omar et al.}

Osawa, T., Y. Sugiyama, M. Inayoshi and S. Kawakishi (1995). Antioxidative activity of tetrahydrocurcuminoids. Biosci. Biotechnol. Biochem., 59:1609-1612.

Ozek, K., K. T. Wellmann, B. Ertekin and B. Tarım (2011). Effects of dietary herbal essential oil mixture and organic acid preparation on laying traits, gastrointestinal tract characteristics, blood parameters and immune response of laying hens in a hot summer season. J. Anim. Feed Sci., 20:575-586.

Radwan, N. L. (2003). Effect of using some medicinal plants on performance and immunity of broiler chicks. Ph.D. Thesis, Poult. Nutr. Dept. Fac. Agric. Cairo University

Radwan, N.L. and A. M. Abdel-Khalek (2007). Response of summer stressed growing rabbits to some dietary growth promoters. Tartu Estonia "Animal health, animal welfare and biosecurity, 1:350358.

Radwan, N. L., R. A. Hassan, E. M. Qota and H. M. Fayek (2008). Effect of natural antioxidant on oxidative stability of eggs and productive and reproductive performance of laying hens. Inter. J. Poult. Sci., 7: 134-150.

Saki, A. A., R. N. Harcini, E. Rahmatnejad and J. Salary (2012). Herbal additives and organic acids as antibiotic alternatives in broiler chickens diet for organic production. African J. of Biotechnology, 11:2139-2145.

Silva Cardoso, V., C. A. Rineiro de Lima, M. E. Freire de Lima, L. E . Gomes Dorneles and D. M. Gracas (2012). Piperine as a phytogenic additive in broiler chickens. Pesqisa Agropecuaria Brasileira, 47:4.

Spais, A. B., L. A. Giannenas, P. Fluorou-Paneri, E. Christaki and N.A. Botsoglou (2002). Effect of Gene $\mathrm{x}$, a feed additive containing organic acid and herb extracts on the performance of broiler chickens. J. Hellenic Vet., 53: 247-256.

SPSS (2007). User's Guide: Statistics. Version 16. SPSS Inc. Chicago, IL, USA.

Tiihonen, K., A. C. Ouwehand and N. Rautonen (2010). Human intestinal microbiota and healthy ageing. Ageing Res. Reviews 9: 107-116.

Williams, P. and R. Losa (2001). The use of essential oils and their compounds in poultry nutrition. World Poult. Sci., 17:14-15.

Ziggers, D. (2011). Animal Feed News. EU 12-point antibiotic action plan released, 18 November, 2011. Accessed Dec. 9, 2011. http:// www.allaboutfeed.net/news/eu-12-point-antibiotic-action planreleased-12443.html. 
إضافة الزيوت الضرورية والأحماض الدهنية متوسطة السلسلة في العلائق وتأثير ها على الأداء الإنتاجي لبداري التسمين

\author{
عصمت محمد عمر' ، وليد حسين أحمد محمد' ، هاله محمد عبد الواحدّ ومنى سيد رجب' \\ 'كلية الزراعة - قسم اللدواجن - جامعة الفيوم- الفيوم- مصر.

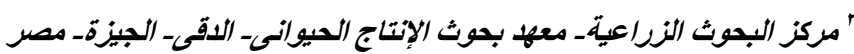

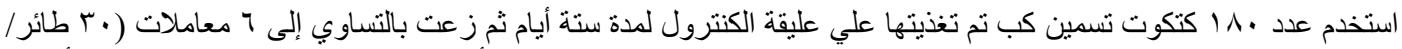

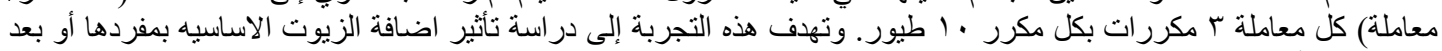
خلطها مع الأحماض الدهنيه متوسطة السلسلة في علائق بداري التسمين على الاداء الانتاجي.

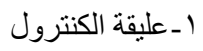

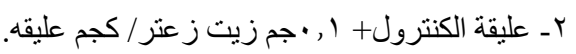

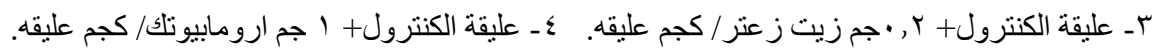

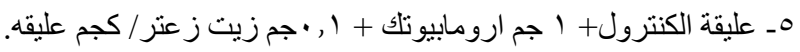

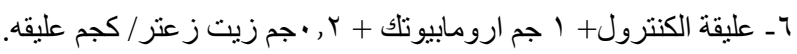

$$
\text { وتم تلخيص النتائج المتحصل عليها كما يلي: }
$$

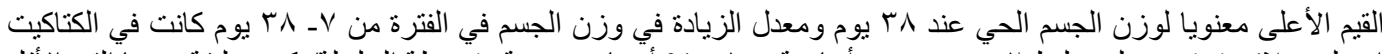

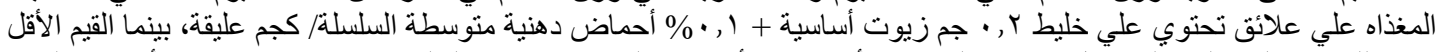

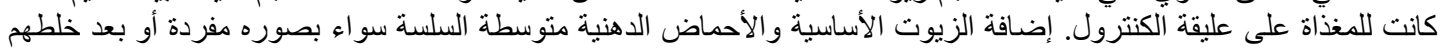

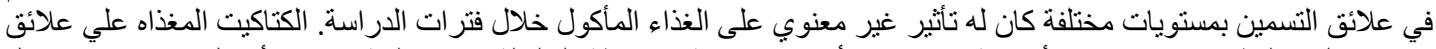

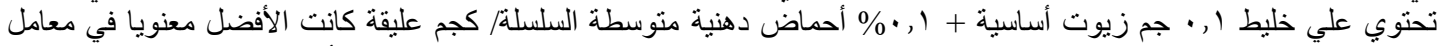

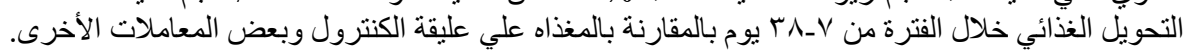

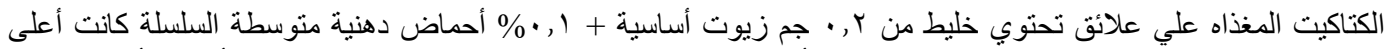

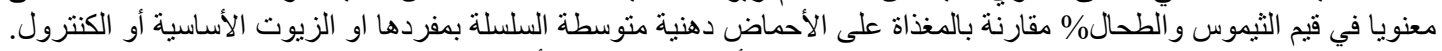

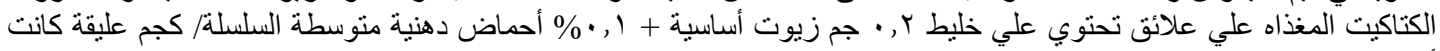

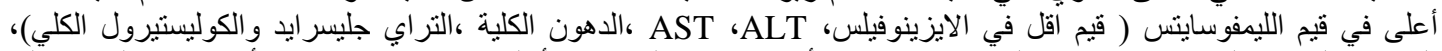

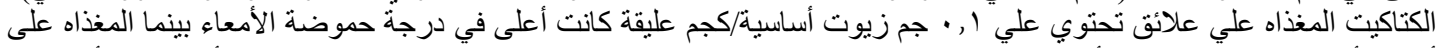

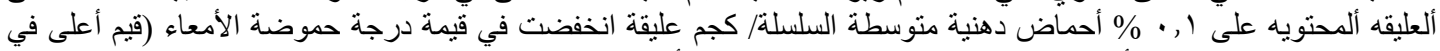

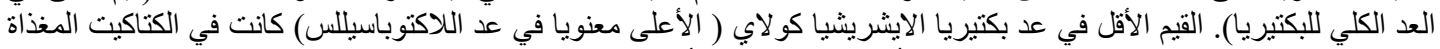

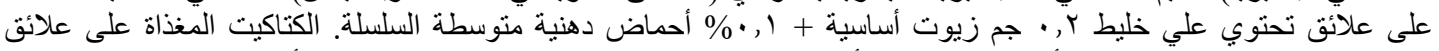

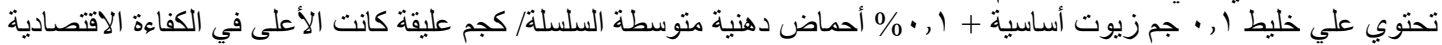

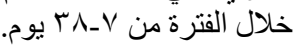

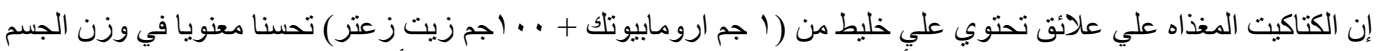

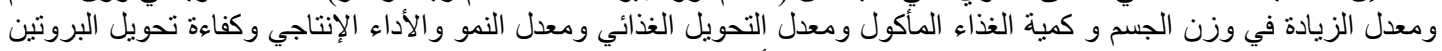
و الطاقة وبعض صفات الهيماتو لوجي و المناعة وميكروفلور الأمعاء و الكفاءة القتصادية. 


\section{Omar et al.}

